\title{
International Market for Higher Education and a Higher Education Policy: The Case of France and China
}

\author{
Darya Loyola (Tyutereva) \\ University Paris 2 Panthéon-Assas
}

\begin{abstract}
Higher education policies are more and more influenced by the competition on the market for higher education. With the appearance of several world universities rankings this ever growing competition of universities for best students officially became international. In order to up-grade their status and become more attractive for international students the higher education actors have to develop their internationalization strategy. In the 2000s time several works on the international market for higher education appeared. In this article we continue to raise questions related to the influence of the international market for higher education. The aspect that we would like to cover in our research is the changes that high education policy open for internationalisation brings to the national education system and culture. We see the link between public policies and a concurrence on the international scale of higher education institutions. This concurrence is driven by the world-recognised highly ranked American and British institutions which belong to the higher education culture of the capitalist economic system of the developed states. The policy of internationalisation makes other higher education models based on the different structures and traditions follow the leaders of the international market of education and modify their systems. In this article we present our research project with the review of the sources, the problem statement and the research methods.
\end{abstract}

\section{Introduction}

Annual increase in the number of students enrolled in a country of which they are not citizens ignifies the growing demand for internationally recognized university education. This growing demand intensifies the competition between universities from all over the world. Universities compete in the market for higher education and make their efforts to attract international students by offering them prestigious degrees, better conditions for study, easier access to higher education that guarantees them fair employment opportunities. The appearance of rankings boosted this competition dramatically. Not only the universities all over the word adapt their curricula and management, but the states adopt and pursue the policy of attractiveness to promote their higher education institutions abroad and increase their competitiveness in the international market for higher education. If we take a look on the web-sites of the ministries of higher education we will see in the headings the references to Shanghai Jiao Tong ranking or Times Higher Education World Universities Rankings with the statements of higher education policy decision makers on the necessity to elaborate effective strategy of attractiveness for national institutions [1]. The national drafters of the policy of attractiveness take into consideration the world's recognition of American and British institutions and inspire themselves not only from their organization and management, their strong research and science constitutive, but also the whole system they are originated from. The strategies of internationalization these drafters develop both in their governments and in the higher education institutions, lead to structural changes to their higher education systems and bring challenges to higher education cultures. Therefore, the international competition between universities and the perception of the existence of the international market drives higher education systems to the new frontiers. In two last decades international market for higher education has undergone the significant changes both regionally and globally. In Europe, international mobility has augmented highly since the beginning in 1999 of Bologna process. Thanks to Erasmus exchange program existing since 1987 Europe has become a "melting pot" of students. The popularity of this program is growing in geometric progression. Asian countries which have been for a long time the main consumer of higher education abroad change their strategies and, trying to gain more intellectual force, invest in their own institutions in order to attract the best international students.

Globally, we see the emergence of new actors in the international market in higher education. The "emerging" countries who wish to play a more important role in the field of education and research are entering the market to compete with its leaders. In 1988 , China was only a minor contributor to the international science, providing little more than $1 \%$ of scientific articles. In the late 2000s, China's contribution to scientific articles is $10 \%$, and the country has become the second largest science contributor. Many other emerging countries have increased dramatically their research forces: Thailand, Malaysia, Singapore, South Korea, Taiwan, Turkey, India, Chile, South Africa, 
Australia, Egypt, and Brazil [2]. These new players on the education and research market are to adapt their internationalization strategy and conduct their policies taking into account the functioning of the market, trends and competitors offer.

The United States and the United Kingdom are the long term leaders on the international market for higher education. Their prestigious institutions and a long-term relationship with marketization of higher education are major factors of their supremacy. Anglo-American university model is the center of excellence for international students. This leading status is confirmed by the rankings which are the real tools on the international market of higher education as they give the idea of ideal university model, the qualities of the institutions to develop and a higher education model to learn from.

\section{Studies of the international market for higher education}

The understanding of how this market works and its general observations are now nourished by several scientific works delivering the analyses of the market and certain aspects of its functioning. First of all, there are statements that market does exist and the attempts to give definitions. The comprehensive analysis was undertaken by Simon Marginson. In his article "Competition and Markets in Higher Education: a 'glonacal' analysis" [3]. Marginson defines the international market for higher education and underlines the importance of marketization for higher education. Universities produce "status goods" and create social competition which is beyond the economic scale. Round Backer, in the book 'The' Market for Higher Education:

Does It Really Exist?', gives arguments that market really exists, and analyses the economic dimension of the market [4].

While above mentioned authors are persuading us on the existence of the market and gives us the ideas of its substance, other authors do not doubt of the existing of the market and suggest their opinions on its development: market trends and a market evolution. There is a book published in 2001 "The global market for higher education: sustainable competitive strategies for the new millennium" in which its authors T. Mazzarol and Geoffrey Norman Soutar enlist the trends for higher education world dictated by market to be considered by universities in the nearest future [5]. In 2011 the same authors look back and confirm their feelings about trends predicted in 2001. There are also predictions about the future of market itself. In 2003 Times Higher Education published an article "The global market bubble" of Philip Altbac, an expert in higher education, who warns the market actors that they should take the precautions and not saturate the market, because like any other market it can become "bubbled" [6]. In 2013 Philip Altbac was offered a seat in one of the Councils for the Ministry of Education and Science of Russian Federation to deliver his advice on promoting the international competitively of Russian universities.

As the topics of higher education internationalization and market strategy have obviously become fashionable in the academic world in the 2000s it created the necessity for advice on higher education management. Governmental and non-governmental organizations set up to promote higher education values nationally and internationally take this opportunity to deliver the opinions how to promote an institution abroad. There are, for example, marketing plans proposed by European Association of International Education in their work "Marketing your institution internationally [7] to get purchased by universities policy decision-makers so they could improve their internationalization strategy according to the market demands. There are also strategies proposed by national and international experts in higher education to their countries and to other countries seeking their expertise. There is, for example, a report released in 2008 and then in 2011 [8] by Drummond Bone on the internalization of higher education and the strategy of the United Kingdom on the market for higher education.

Finally, there are few works touching the aspect of market influence on public and institutional policy. In his article "Allowing market to rule: the case of the United States" David D. Dill [9] is undertaking a study on higher education markets and market influence on the evolution of American universities. It is particularly possible to trace American strategy throughout time and to see the evolution of higher education system changing by the market rules. While reading this article, we ask ourselves questions: what would be the evolution of other higher education systems influenced by market? What changes it might bring? Those states with ambitions to get more "soft-powerful", would they accept the American rules of the higher education market? How would it influence their higher education culture and higher education system?

\section{Problematic of market influence on higher education policy of different countries}

Even though we can conclude that thinking about certain aspects of the market effects on public policy and university management is initiated, the fact is that the authors of the above mentioned works mostly belong to and make their observations from the perspective Anglo-American-Australian world of higher education with its high tuition stakes and 
businesslike policies for universities of capitalist economy. None of this thinking is yet advancing in the socialist economies, for example. In Italy or France the tuition fees are very modest according to the Anglo-American world. Also, the financing comes from the states and not from the private foundations. And last, but not the least, the basic principle of the higher education world is a fair access to the education, the principle of equality. It is to know if the countries whose higher education systems, structures and cultures are different from those of the market leaders (United Kingdom, USA, Australia) would take the higher education market as it is taken in Anglo-American world and adapt their strategies according those proposed by the leaders and modify their systems according to the leaders systems. This aspect: the impact of international market on higher education policy of different states seems unexplored and needs attention.

We feel the necessity to deepen the subject and conduct an analysis on how the international concurrence between the universities influences the public policies and bring changes to higher education culture. The angle that we want to explore is the policies of countries faced to choose the internationalization strategy to compete with other universities. This competition indicates them the existence of the international higher education market and, therefore, force countries actively involved in student mobility to consider this market process, to adapt and to look for its strategy. The model they choose is the ideal university model promoted by international rankings. In order to achievement some of the qualities of this model's not only they invest in modifying university but they change the higher education system. To see the policy evolution and the system changing we would like to analyze two cases - two counties with firm ambitions on the international market for higher education, with a great potential and most importantly whose higher education systems and culture are different from Anglo-American model.

\section{The case of France and China}

Analyzing different indicators of international market for higher education we decided to focus our research on France and China. The choice of these two countries is justified by several reasons. First of all, China and France have a large market potential. France is a very active player in the global student mobility as well as in European exchange programs [10]. Currently we observe a certain disbalance between incoming mobility and outgoing mobility in French universities [11], which is an argument in favor of French higher education attractiveness. France is one of the symbols of the Bologna process, as it is one of the countries that have initiated it. In the beginning of 2000s we saw several American works dedicated to the analysis of the potential threat of Bologna process for the market share of American universities on the market for higher education [12]. France offers several advantages, as accessibility to higher education for international students: foreigners can get into the university paying same fee as nationals and the cost is not that high. French social system and health care system are respected abroad. In addition, France is the capital of $\mathrm{La}$ Francophonie that unites 75 countries by language, cultural and historical links.

China is an "emerging" state, which, with its economic success, is trying to assert its position on other grounds, particularly education and science. With is gaining "soft power" strategy, it has now become the second largest scientific contributor. For a long time, China remained a "consumer" of higher education abroad. Currently, the country heavily invests in programs to promote its institutions (Projects 2011, 985, C9 league, creation of China scholarship Council). So China makes efforts to make her place on the market for incoming mobility. Secondly, none of the countries belong to the AngloAmerican tradition of higher education. For a long time, and today, the United States, the United Kingdom and Australia dominate the market. These are the main host countries of foreign students [13]. It is particularly interesting to analyze the nonAnglo-American countries and their behavior in the face of market leaders. Given that British and American higher education systems have been analyzed in many articles, our goal is not to restate their characteristics. Existing and available information will be used for our comparative study of these systems with current French and Chinese reforms influenced by international competition.

The questions that we ask are as follows:

- What are the strategies of China and France?

- How have education offers in these countries changed over the years on the international market for higher education?

- What are their instruments to influence the market? How do they adapt to new market trends?

- What is the role of the state in the internationalization of higher education process?

- What is the relationship between the state and higher education institutions?

- What is the degree of autonomy of universities in achieving the internalization strategy?

- What is the role of teachers and researchers?

- What are the results of reforms aimed to expand the international presence?

- How do institutions change?

- How this affects the higher education system? 
We would like to see how institutions change, strategies to define how the system improves its competitiveness: the evolution of the education system with the process of internationalization and entry into the international market. We propose a comparative study that involves the comparison of past and current systems of countries to measure the evolution of the system during the period of twenty years, from 1990 to 2010. This period represents important geopolitical changes in the world and also, some significant moves in the higher education policy of both countries.

The governmental initiatives of France and China for 2 last decades show the determination to make the education models more attractive. France signed in 1999 the appeal of the construction of the European Higher Education Area, created in 2007 organisation Campus France to promote French education abroad and promulgated the law regarding the liberty and the responsibility of the universities. China introduced two important laws on education in 1995 and in 1998, launched the programmes 211 and 985 to increase the international role of Chinese universities and invested heavily in the attraction of foreign scholars. The "Chinese Government Scholarships - University Postgraduate Study Programme", set up by the Ministry of Education of China (MOE) in 2008, is aimed at promoting China's higher education. Enrolment is managed directly by China's key universities with now more than 10,000 scholarships to foreign students 14 . The 9 universities of 985 project made up the C9 League in 2009 [15], which is referred to as the Chinese equivalent of the US Ivy League. Enlarged from 9 to 39 universities sponsored by the funds for this project, the door was closed for other universities in 2011 and it was announced that no more new schools could join in.

The above mentioned government initiatives and laws of two countries bring important changes into the status of universities, their financing and government which seem inorganic with the main traditions and principals of higher education culture in France and China. Our preliminary analysis reveals that in France, the changes contradict the principles of equality of the social state, and in China, the changes the Chinese traditions of hierarchy and centralisation. We would like to draw your attention to the article of Christine Musselin «Vers un marché international de l'enseignement supérieur? » published in 2008 [16] where the author analyzes the reforms of French higher education after Bologna process asking herself if it could be the impact of the international market for higher education and the signification of the appearance of this market for France. French historian of higher education Christophe Charles, the author of the book "Histoire des universités" admits that one of the trends of French higher education is the merchandialization of knowledge which is unnatural to French higher education culture and which nevertheless influences the public policy. We had an opportunity to interview Christophe Charles, who says that "excellence is very difficult to define, however European universities are obsessed with excellence as well as our politicians".

There are also some works on the foreign influence on Chinese higher education. Yuzhou Cai, in his article "Traditional reform philosophy and challenges of higher education reforms in China" published in 2012 talking about Chinese higher education culture that comes into a conflict with reforms inspired by American model [17]. The new challenges for changing Chinese higher education system were highlighted earlier by Kathrin Mohrman in her article "Emerging Global Model with Chinese characteristics" [18], more particularly the necessity for institutional autonomy and academic freedom. We conclude that there is a confirmed sense of the impact of external force on a public policy of both countries. There are also questions if there is an impact of competition that pushes universities and counties to learn more about this market and inspire themselves from the market leaders.

If we look at the frequent statements of the high level managers of higher education institutions (presidents, vice-presidents, rectors) of both countries in question we will see that local higher education decision-makers mention often the importance of a strategy on the international market led by the world-recognised highly ranked American and British institutions. Given the fact that institutions become more autonomous with above mentioned reforms, would these education decisionmakers pursue the marketization policy within their institutions? Seeking for a successful strategy would they change their institutions according to market models? We would like to show how the success of Anglo-American model on the international market of education has an impact on French and Chinese models based on the different foundations, structures and traditions. We want to see how the international competition between universities influence public policies both in the government and in the institutions and if it is possible to measure this impact, to find out to which degree the influence works and how it changes the national system. We will prove the hypothesis that this influence is visible in the policy more favorable for the decrease of the role of the state, for the increase of private funding and for the appearance of highly selective university system, in other words, the academic capitalism.

\section{Research methods}

To see the evolution of the national systems of education in the international context we count to follow the events on the international market of 
higher education within the target period and also the evolution of the positions of the two countries in question on the international market. This analysis will be qualitative and not quantitative as we want to go beyond the statistics that already exists. We have available data provided by UNESCO, the OECD; the Agency reports Campus France or the European Commission, the Ministries of Education, Ministries of Foreign Affairs relating to certain aspects of the international cooperation and student mobility.

The profound analysis of the reforms results and modifications of the education system during two last decades is essential. This analysis is an empirical research that is to gather new data and new facts, and has referred to answer the research question: does the internationalization strategy driven by competition generate changes in the education system? It is an explanatory research that aims to find the causes, principles or laws that can account for the phenomena.

To examine the strategies of the institutions and the evolution of their offers (academic programs offered to foreign students) the field research is crucial. The field research will take place in the institutions and will consist of the interviews with actors involved in the development of internationalization strategy. In both countries higher education institutions, these are the presidents, vicepresidents responsible for international missions, international relations administrators, delegates and teachers in charge of international cooperation. The opinions of teachers and researchers are particularly interesting and useful for student mobility always comes after the establishment of links between teachers and researchers who cooperate with their foreign colleagues. We plan to study the possibility to meet with administrative staff contribute to public higher education policy. This possibility will be investigated.

During these interviews we will gather the information about the strategy and practices of the institutions for the last 20 years. Those national and local actors will help us to formulate their conceptions of the international market for higher education, state their orientations, their missions and their strategies. Also we want to find out what changes they bring, they have experienced and they are intended to pursue. Another result of the field research will be the analysis of the evolution of the institutions and its offers.

For the field research we select the institutions which participate actively in the process of internationalization*. We developed several criterions for both countries in question. For France we chose the universities with highest incoming mobility and the biggest growth in the international mobility. All together these institutions should cover from $80 \%$ to $90 \%$ of incoming mobility. Both types of mobility are considered (individual and on the exchange programs). Among the 1,456 higher education institutions in France (and DOM) we chose 102 universities. For example, all the universities of the academies of Paris, Creteil, and Versailles were chosen because together (17 universities) they are home to more than $32 \%$ foreign students, a figure that makes the region Ile de France the most popular destination. Second, we chose the Academy of Nice (2 universities) in absolute value, as there are higher rates of foreign students: $18.2 \%$ compared to the total population (average in France is $12.3 \%$ ). Third, we chose the Academy of Clermont-Ferrand (2 universities) for the highest increase of the number of foreign students between 2005 and 2009 (32.6\%). This statistics is provided by Campus France [19]. As for the field study in China the several criterions are as follows:

1) the largest strange students enrolled in the school number,

2) the highest rate of foreign students compared to the total population, and

3 ) the largest increase in the number of foreign students between 1990s and 2010s, and

4) the most important investment in the university from the state,

5) participation in projects 211 and 3985, and the party in C9 League (considered the establishment of institutions - key to progress of Chinese higher education and research in China by the Chinese government)

6) place in rankings global universities. Together universities must cover more than $80 \%$ of the incoming student mobility.

Among the 2101 Higher Education in China there are 197 institutions that accept foreign students in individual mobility (data of Education of the People's Republic of China Ministry [20]). So we chose 95 schools from 197 to study their internationalization strategies and the evolution of their training offerings on the international higher education market. These institutions represent the Chinese higher education system in the internationalization process - they are key players in the strategy attractive to Chinese higher education.

We would like to give you some examples of the question we postulate:

- What is an international market for higher education?

- Does the international competition play an important role nowadays?

- Which international trends do you think the higher education institutions should consider while deciding on the institutions' global strategy?

- What is your institution internationalization strategy?

- What does your university do to attract international students? 
- How do the academic programs change since your institution accepted international students?

- What is your institution fee policy towards the international students?

- What is your mission? Etc.

We are intended to ask "open" questions to gather the opinions, compare them and mark out the common and specific traits of institutions policies. Our analysis is aimed to dig deeper into the comprehension of international market for higher education by international higher education decision makers. We set up to prove the hypothesis that higher education system open to internationalisation and steps into the competition is subjected to many modifications which are unfamiliar to the national higher education culture. On the global picture it could improve our vision on one of the aspects that influence the path of the higher education. In practice, we want to show the reflections of the higher education actors of different systems and cultures, their inclinations to marketization of their institutions:

- Do they try to move to global capitalism or specific capitalism?

- Or do they continue their battle for academic socialism or even communism?

* At the moment we are conducting our field research in France and would be happy to share the exciting results with you by the beginning of 2014 .

\section{References}

[1] France (Communique of 14.08 .2012 of the minister Geneviève Fioraso) http://www.enseignementsuprecherche.gouv.fr/pid24665-cid61215/classement-deshangai-2012-stabilite-des-etablissementsfrancais.html (23 November 2012).

[2] Baron, M., Eckert D., and Jégou, L. 'Peut-on démêler l'écheveau mondial des collaborations scientifiques?', Web of Science database (Thomson Reuters) treatment. http://mappemonde.mgm.fr/num30/internet/int11201.html (15 August 2012).

[3] Marginson, S., 'Competition and Markets in Higher Education: a 'glonacal' analysis', Policy Futures in Education, 2(2), 2004, 175-244, http://dx.doi.org/10.2304/ pfie.2004.2.2.2 (20 May 2012).

[4] Becker, William E. and Round, David K., 'The' Market for Higher Education: Does it Really Exist?. IZA Discussion Paper No. 4092.; http://ssrn.com/Abstract=137 3326 (20 May 2012).

[5] Mazzarol, T., Soutar G. N., The global market for higher education: sustainable competitive strategies for the new millennium Elgar Monographs, Elgar Publishing, Incorporated, 2001.
[6] Altbach P.G., "The 'Global Market' Bubble," Times Higher Education (February 14, 2008); http://www.timeshighereducation.co.uk/400584.article (20 May 2012).

[7] European Association for International Education, http://www.eaie.org/home/publishing/order-a-publication. html (15 May 2013).

[8] Drummond Bone, J., 'Internationalization 2011: An overview', Higher Learning Research Communications June 2011 Volume 1, Number 1.

http://journals.sfu.ca/liu/index.php/HLRC/article/view/41/ 37.

[9] Dill, D. D, 'Allowing the Market to Rule: The Case of the United States. Higher Education Quarterly, Volume 57, Issue 2, pages 136-157, April 2003

[10] Enquête exclusive Campus France - TNS Sofres 'Les étudiants étrangers en France: image et attractivité', Lesnotes n ${ }^{\circ} 34$ - Octobre 2011 de Campus France.

[11] Statistiques concernant les étudiants étrangers inscrits à Paris 1: 2005 -2008. Service des relations internationales, Avril 2009, Université Paris 1 Panthéon-Sorbonne. Ministère de l'Enseignement supérieur et de la recherche, direction de l'évaluation, de la prospective et de la performance, L'état de l'enseignement supérieur et de la recherche en France. 3à indicateurs ; n², décembre 2008.

[12]'What is the Bologna Process, Why Should We Care, and What Might It Mean For Higher Education in the U.S.?' - workshop organized by The Bologna Process Advisory Group at University of Minnesota; Paul L. Gaston III, ' The Challenge of Bologna, What United States Higher Education Has to Learn from Europe, and Why It Matters That We Learn It'. January 2010.

[13] Data of Camus France: Chiffres clés 2009, http://www.campusfrance.org/fr/ressource/les-etudiantsinternationaux-chiffres-cles-2009. (20 May 2012).

[14] China Scholarship Council http://en.csc.edu.cn/ (20 August 2012).

[15] China Education and Research Network, http://www.edu.cn/gao_jiao_news_367/20091029/ t20091029_416411.shtml, http://english.peopledaily.com. cn/203691/7822275.html). (20 August 2012).

[16] Musselin, C., «Vers un marché international de l'enseignement supérieur?», Critique internationale Presses de Science Po, Juin 2008, n³9, pp. 1-23.

[17] Yuzhou Cai, 'Traditional reform philosophy and challenges of higher education reforms in China', International Journal of Humanities and Social Science. Vol. 2 No. 6 Special Issue- March 2012, pp. 60-68.

[18] Mohrman, K., "Emerging Global Model with Chinese characteristics" Higher education Policy, 2008, 21, pp. 2948.

[19] Les notes de CampusFrance, Janvier 2012 - nº 36. 
International Journal for Cross-Disciplinary Subjects in Education (IJCDSE), Volume 4, Issue 3, September 2013

[20] Web-site of the Ministry of education of People's Republic of China, http://www.moe.edu.cn/publicfiles/ business/htmlfiles/moe/moe_2812/200906/48836.html (20 February 2013). 